\title{
The systematic status of the Libyan bats of the genus Plecotus (Chiroptera: Vespertilionidae)
}

\author{
Systematická posice libyjských netopýrů rodu Plecotus \\ (Chiroptera: Vespertilionidae)
}

\section{Friederike SPITZENBERGER}

Natural History Museum Wien, Burgring 7, AT-1010 Wien, Austria; friederike.spitzenberger@aon.at

received on 5 December 2020

\begin{abstract}
This paper briefly reviews the taxonomic history of the Plecotus kolombatovici complex, the bat populations which occur in isolated ranges surrounding the Mediterraean Basin, including Maghreb, Tripolitania, Cyrenaica, Anatolia, Balkans, and Italy, plus numerous Mediterranean islands. Since this complex exhibts genetic characters close to Plecotus teneriffae from the Canary Islands, the samples of the complex from Cyrenaica (NE Libya) were described as a subspecies P. teneriffae gaisleri. However, this name was later used for all populations of the complex inhabiting North Africa as P. gaisleri, a full species separated from $P$. kolombatovici. However, the available results of molecular genetic analyses of the complex support the opinion that these allopatric populations are conspecific and referrable to $P$. kolombatovici and reopens the question regarding the systematic status of $P$. teneriffae.
\end{abstract}

Key words. Plecotus teneriffae, Plecotus kolombatovici, Plecotus gaisleri, Cyrenaica, taxonomy.

In the context of species protection issues, a question regarding the systematic status of long-eared bats occurring on Malta and Pantellaria arose. This article tries to clarify the complex taxonomy of Plecotus kolombatovici, a bat that occurs in often isolated Mediterranean landscapes around the Mediterraean Basin: Maghreb (Morocco, Algeria, Tunisia), Tripolitania and Cyrenaica (Libya) in the south, and Anatolia, Greece, Albania, Croatia, and Italy in the north (Juste et al. 2004, Benda et al. 2004, Spitzenberger et al. 2006, AnCillotto et al. 2019). Furthermore it has been recorded on numerous islands in the Adriatic and Aegean Seas, plus in Crete and Cyprus.

For about 150 years, systematists have referred all western Palaearctic long-eared bats to a single species, Plecotus auritus (Linnaeus, 1758), due to the lack of obvious phenetic differences within or among populations. Plecotus christii Gray, 1838 was the first taxon to be described as a species of its own; it was followed by Plecotus teneriffae Barret-Hamilton, 1907 and P. balensis Kruskop et Lavrenchenko, 2000, However, the former two names were considered just subspecies either of $P$. auritus or P. austriacus for a long time (HANÁK 1966, HoRÁČEK et al. 2000). Plecotus austriacus (Fischer, 1829), originally described as a variety of $P$. auritus, was elevated to species rank by BAUER (1960), and twenty years later Đulić (1980) described a new subspecies of this bat from coastal Croatia, P. austriacus kolombatovici Đulić, 1980. Recognition of similarities of $P$. teneriffae and $P$. austriacus kolombatovici by DE PAZ (1994) was the last important contribution to the classification of the western Palaearctic long-eared bats based solely on morphological analysis.

Only the advent of genetic analyses shed light into the rich diversity of taxa within the genus Plecotus but also gave rise to considerable confusion and controversy regarding the taxonomy of these taxa. "It is 
only with the recent use of molecular characters that the evolutionary picture of the Palaearctic Plecotus has begun to be unveiled" (JUSTE et al. 2004: 1121).

Genetic analyses of populations of the $P$. austriacus clade established species rank of $P$. kolombatovici (MAYER \& VON HelverSEN 2001) and confirmed species status of P. teneriffae (Juste et al. 2004) as had been already suggested by IBÁÑEZ \& FERNANDEZ (1985).

Based on analyses of mitochondrial genes, (1) Juste et al. (2004) classified the North African Plecotus samples as P. cf. kolombatovici (Cyrenaica) and Plecotus sp. (Morocco); (2) Benda et al. (2004) assigned all Plecotus populations from Croatia, Turkey, Libya, and Morocco to P. teneriffae, described populations from Cyrenaica as a new subspecies, P. teneriffae gaisleri Benda, Kiefer, Hanák et Veith, 2004, and named the bats from Tripolitania and Morocco P. teneriffae cf. gaisleri; (3) SPITZENBERGER et al. (2006) treated $P$. teneriffae and $P$. kolombatovici as two separate species and found three distinct subspecific groups in the latter species: (a) Croatia and Turkey, (b) Cyrenaica, and (c) Morocco; (4) in a comprehensive study comprising material of two bat families and numerous genera, and P. austriacus, $P$. christii, P. t. gaisleri, P. kolombatovici, but not P. teneriffae, MAYER et al. (2007) suggested elevating P. t. gaisleri to the species rank; (5) based on analyses of a comprehensive multilocus molecular dataset (in total 96 samples of six Plecotus taxa, including P. kolombatovici complex) from a wide geographic scope, ANCILlotTo et al. (2020) assigned samples from Malta and Pantelleria to P. gaisleri and provided ample information on intra- and interspecific divergences (p-distances) which clearly separated valid species (P. austriacus, $P$. christii, $P$. kolombatovici) from allopatric populations of $P$. kolombatovici plus $P$. teneriffae. While p-distances (16s gene) between the full species varied between $4.71 \%$ and $6.78 \%$, the variation within $P$. kolombatovci plus $P$. teneriffae was between $1.31 \%$ and $2.75 \%$.

This result supports the opinion that all allopatric populations (including those from Cyrenaica) of $P$. kolombatovici are conspecific and reopens the question regarding the systematic status of $P$. teneriffae. Not least because of the highly needed protection of endangered bat species living on islands and in isolated ranges, the systematics of $P$. kolombatovici should be subjected to a thorough study using nuclear markers. Such a study could elucidate the phylogeography of Plecotus kolombatovici and thus complement the series of studies of other bat species with circum-Mediterraean distribution (see BILGIN et al. 2016).

\section{SOUHRN}

Př́spěvek stručně shrnuje taxonomickou historii komplexu ušana balkánského (Plecotus kolombatovici), tedy netopýřích populací, které v isolovaných areálech obývají území obklopující Středozemní moře, včetně Maghrebu, Tripolitanie, Kyrenaiky, Anatolie, Balkanského poloostrova a Italie, a také mnoha středomořských ostrovů. Jelikož tento komplex vykazuje genetické znaky blízké ušanovi kanárskému (Plecotus teneriffae) z Kanárských ostrovů, byli jedinci tohoto komplexu obývající Kyrenaiku (severovýchodní část Libye) popsáni jako samostatný poddruh, P. teneriffae gaisleri. Později však toto jméno začalo být používáno jako jméno druhové pro všechny populace komplexu obývající severní Afriku, jako ušan berberský (Plecotus gaisleri), druh neodvislý od ušana balkánského. Dostupné výsledky molekulárně genetických analys mitochondriálního genomu celého komplexu však podporují názor, že tyto středomořské alopatrické populace představují jediný druh, Plecotus kolombatovici; tím také znovu otevírají otázku systematického postavení ušana kanárského (Plecotus teneriffae).

\section{REFERENCES}

Ancillotto L., Mori E., Bosso L., Agnelli P. \& Russo D., 2019: The Balkan long-eared bat (Plecotus kolombatovici) occurs in Italy - first confirmed record and potential distribution. Mammalian Biology, 96: 61-67.

Ancillotto L., Bosso L., Smeraldo S., Mori E., Mazza G., Herkt M., Galimberti A. \& Ramazotti F., 2020: An African bat in Europe, Plecotus gaisleri: Biogeographic and ecological insights from molecular taxonomy and Species Distribution Models. Ecology and Evolution, 10: 5785-5800. 
BAuER K., 1960: Die Säugetiere des Neusiedlersee-Gebietes (Österreich). Bonner Zoologische Beiträge, 11: $141-344$.

Benda P., Kiefer A., HanÁK V. \& Veith M., 2004: Systematic status of African populations of long-eared bats, genus Plecotus (Mammalia: Chiroptera). Folia Zoologica, 53(Monograph 1): 1-47.

Bilgin R., Gürün K., Rebelo H., Puechmaille S., Maraci Ö., Presetnik P., Benda P., Hulva P., Ibáñez C., Hamidović D., Fressel N., Horáček I., Karataș A., Karataş A., Allegrini B., Georgiakakis P., Gazaryan S., Nagy Z. L., Abi-Said M., Lučan R. K., BartoničKa T., Nicolaou H., Scaravelli D., KaRAPANDŽA B., Uhrin M., PAunović M. \& Juste J., 2016: Circum-Mediterranean phylogeography of a bat coupled with past environmental niche modeling: A new paradigm for the recolonization of Europe? Molecular Phylogenetics and Evolution, 99: 323-336.

Đulić B., 1980: Morphological characteristics and distribution of Plecotus auritus and Plecotus austriacus in some regions of Yugoslavia. Pp.: 151-161. In: Wilson D. E. \& GARDNER A. L. (eds.): Proceedings of the Fifth International Bat Research Conference. Texas Tech Press, Lubock, 434 pp.

HanÁK V., 1966: Zur Systematik und Verbreitung der Gattung Plecotus. Lynx, n. s., 6: 57-66.

HorÁČeK I., HANÁK V. \& GAISLER J., 2000: Bats of the Palearctic Region: a taxonomic and biogeographic review. Pp.: 11-157. In: Woloszyn B. W. (ed.): Proceedings of the VIIIth European Bat Research Symposium. Vol. I. Approaches to Biogeography and Ecology of Bats. Chiropterological Information Center, Kraków, 280 pp.

IBÁÑEZ C. \& FernANDEZ M., 1985: Systematic status of the long-eared bat Plecotus teneriffae Barret-Hamilton, 1907 (Chiroptera; Vespertilionidae). Säugetierkundliche Mitteilungen, 32: 143-149.

Juste J., Ibáñez C., Muñoz J.,Trujillo B., Benda P., Karataș A. \& Ruedi M., 2004: Mitochondrial phylogeography of the long-eared bats (Plecotus) in the Mediterranean Palaearctic and Atlantic Islands. Molecular Phylogenetics and Evolution, 31: 1114-1126.

Mayer F. \& von Helversen O., 2001: Cryptic diversity in European bats. Proceedings of the Royal Society of London, Series B: Biological Sciences, 268(1478): 1825-1832.

Mayer F., Dietz C. \& Kiefer A., 2007: Molecular species identification boosts bat diversity. Frontiers in Zoology, 4(4): 1-5.

DE PAZ O., 1994: Systematic position of Plecotus (Geoffroy, 1818) from the Iberian Peninsula (Mammalia: Chiroptera). Mammalia, 58: 423-432.

Sitzenberger F., Strelkov P. P., Winkler H. \& Haring E., 2006: A preliminary review of the genus Plecotus (Chiroptera, Vespertilionidae) based on genetic and morphological results. Zoologica Scripta, 35: $187-230$. 